\title{
Effect of Milk Fat Substitution of Rennet Milk Induced Coagulation on Physico-Chemical Properties
}

\author{
Imène Felfoul, ${ }^{1,2}$ Salwa Bornaz, ${ }^{1}$ Wiem Belhadj Hmida, ${ }^{1}$ Ali Sahli, ${ }^{3}$ and Hamadi Attia ${ }^{2}$ \\ ${ }^{1}$ Tunisian High School of Food Industries, University of Carthage, 58 Avenue Alain Savary, 1003 Tunis, Tunisia \\ ${ }^{2}$ Alimentary Analysis Laboratory, National Engineering School of Sfax, University of Sfax, BPW, 3038 Sfax, Tunisia \\ ${ }^{3}$ National Agronomic Institute of Tunisia, University of Carthage, 43 Avenue Charles Nicolle, 1082 Tunis, Tunisia \\ Correspondence should be addressed to Imène Felfoul; imenef@gmail.com
}

Received 3 June 2013; Revised 12 September 2013; Accepted 22 October 2013

Academic Editor: Christophe Blecker

Copyright (C) 2013 Imène Felfoul et al. This is an open access article distributed under the Creative Commons Attribution License, which permits unrestricted use, distribution, and reproduction in any medium, provided the original work is properly cited.

\begin{abstract}
The objective of this paper was to study the effect of milk fat substitution by $\left(\mathrm{W}_{1} / \mathrm{O} / \mathrm{W}_{2}\right)$ multiple emulsions based on olive oil in comparison with full and low-fat milks on milk behavior during rennet coagulation. Therefore, based on the turbidimetric and conductivimetric methods, a follow up of enzymatic coagulation is realized. Drainage of renneted gels was followed by syneresis study and cheese yield. The comparison between the coagulation aptitude of low fat milk and milk-olive oil emulsion showed that the hydrolysis phase extended up to 35 minutes for full fat milk and up to 38 minutes for milk-olive oil emulsion. The transition phase solid/gel was shorter in the case of the whole milk. The reticulation phase was shorter in the case of milk-olive oil emulsion. The milk conductivity depended on the milk richness in fat content. Milk-olive oil emulsion showed the lowest cheese-making yield compared to its full and low-fat counterpart.
\end{abstract}

\section{Introduction}

During the last decade, the consumption of low-fat food products has become more than just a trend. In view of the general consensus that the amount and type of fat consumed is important to the aetiology of many chronic diseases (e.g., cardiovascular diseases, cancer, and obesity), there is no surprise that consumers easier adhere to dietary guidelines regarding fat consumption. In fact, to better fit with the relationships between health and diet, a significant change is observed in consumer's behavior to reduced fat variants with sensory and physical characteristics that are close to those of the full-fat standard products.

Due to the crucial role of fat in flavor, texture, and appearance of food, it became clear that the development of reduced-fat products with matching quality of their fullfat counterparts is a difficult task when fat is replaced with alternative ingredients. The substitution of milk fat by emulsified vegetable oils in milk is an option to obtain cheese with healthier saturated/unsaturated fat balance [1]. However, incorporation of emulsified vegetable oils could alter the type, content, and distribution of the fat droplets in the protein network, causing modifications in cheese textural and microstructure behavior [2,3]. Many factors are involved during dairy fat replacement by vegetable fat. As an example, the nature of oil used [4], the size of the emulsion [4], and the nature of emulsifiers employed.

All these parameters could have an effect on physicochemical, textural, rheological, and sensory qualities of the gel obtained also called "reduced fat gel-like product".

Previous studies were focused on milk fat substitution by canola oil [1-4]. Few data were available in literature concerning milk fat substitution by olive oil emulsion. The aim of this paper was, therefore, to study the effect of milk fat substitution by an emulsified olive oil in comparison with full and low-fat milks on milk behavior during rennet coagulation and to compare the curd drainage of these different milk samples.

\section{Materials and Methods}

2.1. Materials. Olive oil (OO) (Chaâl Oil, SOCOHUILE, Sfax., Tunisia) was used as the oil phase of the $\mathrm{W}_{1} / \mathrm{O} / \mathrm{W}_{2}$ 
emulsion. The hydrophilic emulsifier (WE) (P4780, SIGMAALDRICH, St Louis, USA, esters of monoglycerides and diglycerides of diacetyltartaric acid) and hydrophobic emulsifier (OE) (85548, SIGMA-ALDRICH, Chemie Gmbh, CH9471 Buchs, Spain, esters of polyglycerol and polyricinoleate fatty acids) were purchased from SIGMA-ALDRICH France. The biopolymers used were gellan gum (GG) (P8169, SIGMAALDRICH, St Louis, USA) carboxymethylcellulose (CMC) (GA 20529, SIGMA-ALDRICH, CH-9471 Buchs, Steinheim, the Netherlands). The water used in all of the experiments was double-distilled.

2.2. Formulation and Preparation of the $W_{1} / O / W_{2}$ Emulsions. $\mathrm{W}_{1} / \mathrm{O} / \mathrm{W}_{2}$ emulsions were prepared at room temperature using a two-stage emulsification procedure $[5,6]$. In the first stage, a $\mathrm{W}_{1} / \mathrm{O}$ emulsion was made having a $20 \%(\mathrm{w} / \mathrm{w})$ dispersed aqueous phase, a GG concentration of $0.1 \%(w / w)$ and a total emulsifiers concentration of $8 \%(w / w)$ (one part of WE to four parts of $\mathrm{OE}$ ). In all the cases the aqueous inner phase $\left(\mathrm{W}_{1}\right)$ (distilled water $+\mathrm{WE}+\mathrm{GG}$ ) was added drop-wise to the oil phase $(\mathrm{O})(\mathrm{OO}+\mathrm{OE})$ with an Ultra-Turrax homogenizer (Ultra-Turrax H 500 SLT, Service Trade Laboratory Equipment, Germany) at $5800 \mathrm{rpm}$ for $5 \mathrm{~min}$. In the second stage the $W_{1} / O$ primary emulsion was reemulsified in the biopolymer aqueous solution $(0.5 \% \mathrm{w} / \mathrm{w} \mathrm{CMC})$, at $5200 \mathrm{rpm}$ for 10 min using the Ultra-Turrax homogenizer, yielding the following $\mathrm{W}_{1} / \mathrm{O} / \mathrm{W}_{2}$ emulsion. The $\mathrm{W}_{1} / \mathrm{O} / \mathrm{W}_{2}$ emulsion had a dispersed phase fraction of 0.2 .

2.3. Milk Samples. Cow milk used in this study derived from the same breeding spot in northern Tunisia (Holstein breed, BICHE farm, Nabeul region). Once at the laboratory at $4^{\circ} \mathrm{C}, \mathrm{pH}$ was measured; $10 \mathrm{~L}$ batches of milk were added with $0.06 \%(\mathrm{w} / \mathrm{v})$ potassium dichromate against all bacterial growth and immediately frozen at $-10^{\circ} \mathrm{C}$ for further utilizations. $10 \mathrm{~L}$ batches of milk were divided into three equal volumes.

(a) Control full-fat milk.

(b) Low-fat milk which is the result of blending skimmed milk, prepared from full-fat milk centrifugation at $3600 \mathrm{~g} / 15 \mathrm{~min}$, with whole milk (v/v).

(c) Milk-olive oil emulsion obtained by mixing skimmed milk with $\mathrm{X}$ amount of an emulsified olive oil. $\mathrm{X}$ is equal to fat content in control full-fat milk.

2.4. Milk Composition. Total solid and ash contents were determined according to AFNOR methods (1993). The milk $\mathrm{pH}$ was measured using a $\mathrm{pH}$ meter (Model $\mathrm{pH}$ 315i /SET, WTW Inc., Weilheim, Germany) according to N.F. V 04281 [7]. Different nitrogen fractions of milk: total nitrogen $(\mathrm{TN})$, nonprotein nitrogen (NPN), and noncasein nitrogen (NCN) were extracted using the procedure of Rowland [8] and determined by the Kjeldhal method [9]. Fat, calcium and phosphorous contents were measured using, respectively, Gerber method and atomic absorption spectrophotometer [10].
2.5. Rennet Coagulation. Full, low-fat milks and milk-olive oil emulsion were heated at $36 \pm 0.5^{\circ} \mathrm{C}$ for $30 \mathrm{~min}$ and added with $0.35 \mathrm{mLL}^{-1}$ of microbial rennet (M. miehei, strength 1:10000, Laboratories ARRAZI, PARACHIMIC, Sfax., Tunisia) at the normal $\mathrm{pH}$ of the milk.

2.6. Turbidimetric Study and Conductivity Measurement. The turbidity and the conductivity of different milk samples were measured during coagulation using a turbidimeter (Model Analite NEP 160, Turbidity Meter. Mc Van Instruments PTY-LTD, Mulgrave, Australia) and a conductivity meter (Model 18.38 pH/EC meters, EijKelkamp Agrisearch Equipment, Giesbeek, The Netherlands), respectively. Milk samples were initially controlled every 10 seconds for 30 minutes, since turbidity and conductivity change very fast at the beginning, and then every 30 seconds until 1 hour of coagulation and finally every one minute until 5 hours. Turbidity and conductivity profiles have been obtained by plotting these parameters as a function of time. These profiles were used to define the different steps of milk coagulation.

2.7. Syneresis Kinetics. Skim, low fat milk and milk-olive oil samples prewarmed to $35^{\circ} \mathrm{C}$ were coagulated for $1 \mathrm{~h}$. According to Hocine et al. [11], milky curd was cut into equal portion $(1 \mathrm{~cm})$ and placed in a pierced mould at room temperature $\left(20^{\circ} \mathrm{C}\right)$. The weight of expulsed whey was collected each $30 \mathrm{~min}$ for $4 \mathrm{~h}$ and a half. The mass of serum collected after this period was named syneresis capacity.

2.8. Cheese Yield Evaluation. Cheese yield (g/L) was expressed as the quantity of cheese obtained from a given mass of milk ( $\mathrm{g} / \mathrm{L})$ after $4 \mathrm{~h}$ of drainage.

2.9. Statistical Analysis. Analysis of variance (ANOVA) was carried out using the SPSS statistics 19 software. Significant differences $(P<0.05)$ among treatments were detected using Duncan's multiple range tests. Values expressed are means \pm standard deviation of triplicate measurements.

\section{Results and Discussion}

3.1. Milk Composition. The average composition and physicochemical properties of full, low-fat milk, and milk-olive oil emulsion samples are given in Table 1.

It was observed that the difference in $\mathrm{pH}$ of the various milks was not significant $(P<0.05)$ (Table 1$)$. Therefore, it was concluded that fat substitution by emulsified olive oil had no effect on $\mathrm{pH}$. This result confirmed those of Romeih et al. [12] and Kavas et al. [13] who noticed that the combined action of fat reduction and fat replacers addition had no effect on $\mathrm{pH}$.

Table 1 showed that milk-olive oil emulsion contained $\approx$ $15 \mathrm{~g} / \mathrm{L}$ of vegetable fat; this value was almost similar to that of low fat milk.

Milk-olive oil emulsion had a lower dry matter content compared to that of the whole milk sample since it was poorer in proteins but essentially in milk fat (Table 1). Milk-olive oil 


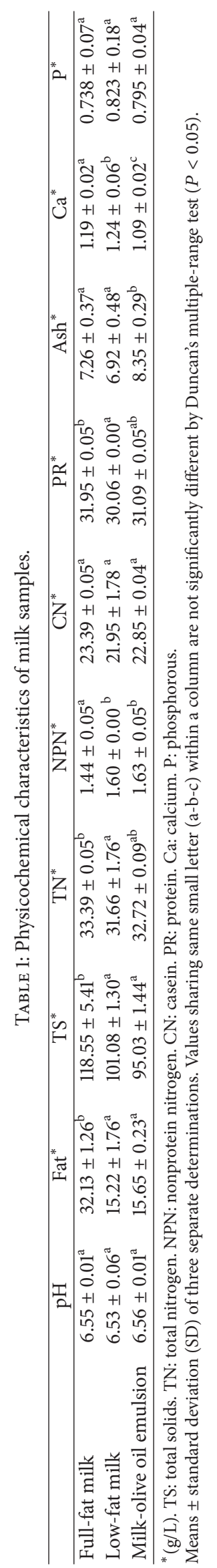




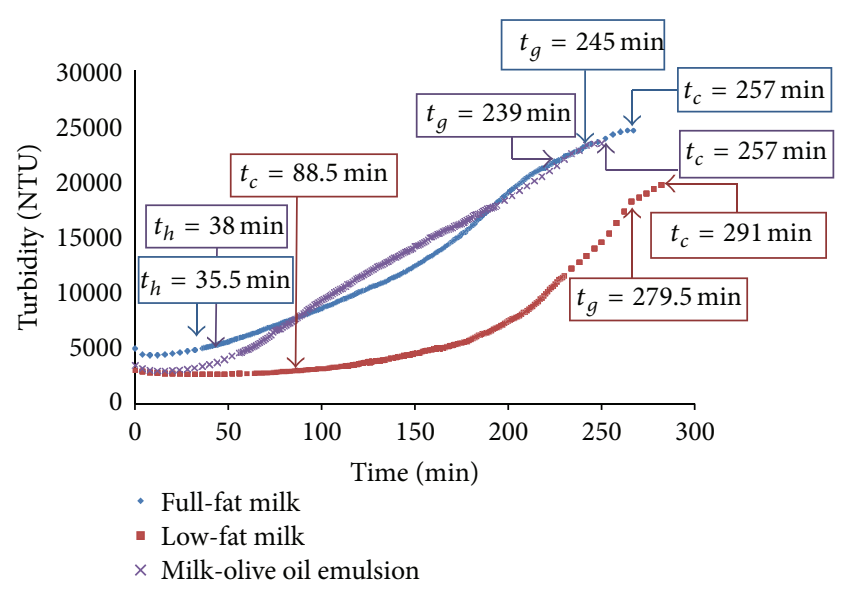

FIGURE 1: Turbidity evolution versus time of various renneted milk samples.

emulsion presented lower total nitrogen content than that of the control whole milk.

The high content in ash of milk-olive oil emulsion was probably attributed to the addition of emulsifiers and stabilizers during the preparation of this sample (Table 1).

\subsection{Renneting Properties}

3.2.1. Milk Turbidity. The enzymatic coagulation mechanisms were common for full, low-fat milk, and milk-olive oil emulsion. In fact, the turbidity data (Tr) obtained during rennet coagulation of these milks showed a sigmoid profile (Figure 1). Based on subsequent works, three phases could be identified. Phase one of latency through which a low variation of turbidity was observed. This phase corresponds to a step of enzymatic hydrolysis. It is characterized by specific proteolysis of casein- $\kappa$ by rennet. The enzyme cleaves the peptidic bond $\mathrm{Phe}_{105}-\mathrm{Met}_{106}$ of casein- $\kappa$ and the protein is divided into two peptids, caseino-macro-peptide and paracasein- $\kappa$. It is situated between " $t_{0}$ " and " $t_{h}$ ", hydrolysis time. The " $t_{h}$ " value is taken as the time corresponding to turbidity variation of 0 NTU.

There was an initial decrease in the turbidity due to the decrease in micelles size presumed to be due to removal of the hairy layer by the rennet.

This observation was in agreement with those of Martin et al. [14] who studied coagulation kinetics of skim and reconstituted milks while following the evolution of the relative viscosity of renneted milks. These authors have measured the viscosity of milk samples as an indicator of the kinetics of the initial stages of coagulation. They explained the first reduction in relative viscosity by the size reduction of casein micelles due to the departure of the glycomacropeptide in the serum.

The second phase corresponds to a micelles aggregation step. During this phase, destabilized micelles were associated to form hydrophobic bonds. This is due to the decrease of surface charges of the micelles when the glycomacropeptide is released in the serum which enabled the association of micelles attacked by the enzyme, facilitating their aggregation.

This phase corresponds to a high increase of turbidity. Since the hairy layer was removed, intermicelle interactions became evident as an increase in turbidity. Insofar, as the cleaved part of the casein is responsible for the stability of the particles, it follows a micellar aggregation resulting in an increase in the turbidimetric signal.

This step is characterized by the presence of an inflexion point of the turbidimetric profile $\left(t_{i}, \operatorname{Tr}_{i}\right)$. Time $t_{i}$, sol-gel transition time, is determined from the derivative of the output signal and materialized by the time at which a peak in speed curve occurs.

This second phase is situated between " $t_{h}$ " and " $t_{g}$ ". The gelation point $\left(t_{g}, \operatorname{Tr}_{g}\right)$ is represented in the first derivative curve of turbidity profile over time, either by a change in the slope, or by the presence of a second peak.

In the third phase, starting at time " $t_{g}$ ", a constant turbidity level is reached when the gel is made. It is a gel restructuration phase, gel formation, and implementation of interactions in the three-dimensional network.

In the case of the milk-olive oil emulsion, obtained by substituting milk fat by emulsified olive oil, the evolution of turbidity was very similar to its counterparts (Figure 1).

The initial values of turbidity recorded for the three samples were 4978.0 NTU, 3044.0 NTU, and 3451.0 NTU for full, low fat milks and milk-olive oil emulsion, respectively (Figure 1$)$. These values differed significantly $(P<0.01)$. It was clear that the measurement of the initial milk turbidity was in relationship with dry matter content and particles size. Sadar [15] and McClements [16] affirmed that the dispersion of the light was as intense as the concentration in particles was important.

The shape of the turbidity curves was the same for all the milk samples. The experimental values of the characteristic points of turbidimetric patterns obtained from different milk samples were illustrated in Table 2. These results showed that there was an important variability between the samples. This high variability in the behavior of different milks has been observed in the registrations of hydrolysis time " $t_{h}$ ", inflexion time " $t_{i}$ ", gelation time " $t_{g}$ ", and coagulation time " $t_{c}$ ".

Table 2 shows that the hydrolysis step characterized by " $t_{h}$ " has extended up to $35 \mathrm{~min}$ for the full-fat milk and up to 38 min for the milk-olive oil emulsion. The caseins hydrolysis was faster in the case of the whole milk. This difference could be due to the accessibility of the enzyme to casein- $\kappa$. This accessibility is dependent of the membrane nature of the fatty globules as well as of the emulsion size which might modify the possible interactions that could exist between casein and milk fat.

From Tables 1 and 2, it was shown that dry matter content of full-fat milk was statistically higher than that of milk-olive oil emulsion $(P<0.05)$. However, there was no statistical difference in hydrolysis phase duration between these two milk samples $(P<0.05)$. This result confirmed those found by Bornaz et al. [17] and Remeuf et al. [18] who showed that the composition of cow milk had no influence on the duration of hydrolysis phase. Furthermore, Lomholt and Qvist [19] 
TABLE 2: Experimental values of characteristic points of the enzymatic coagulation of the milk samples (min).

\begin{tabular}{|c|c|c|c|c|c|c|c|}
\hline & $t_{h}$ & $t_{i}$ & $t_{g}$ & $t_{c}$ & $t_{g}-t_{h}$ & $t_{c}-t_{g}$ & $t_{g}-t_{i}$ \\
\hline Full-Fat milk & $35.5 \pm 0.71^{\mathrm{a}}$ & $176.5 \pm 2.12^{\mathrm{a}}$ & $245.0 \pm 5.66^{\mathrm{a}}$ & $257.0 \pm 4.24^{\mathrm{a}}$ & 209.5 & 12.0 & 68.5 \\
\hline Low-Fat milk & $88.5 \pm 3.54^{\mathrm{b}}$ & $271.0 \pm 8.49^{c}$ & $279.5 \pm 13.44^{\mathrm{b}}$ & $291.0 \pm 7.07^{b}$ & 191.0 & 11.5 & 8.5 \\
\hline Milk-olive oil emulsion & $38.0 \pm 1.41^{\mathrm{a}}$ & $232.0 \pm 11.31^{\mathrm{b}}$ & $239.0 \pm 11.31^{\mathrm{a}}$ & $247.0 \pm 11.31^{\mathrm{a}}$ & 201.0 & 8.0 & 7.0 \\
\hline
\end{tabular}

$t_{h}$ : hydrolysis time; $t_{i}$ : time at the point of inflection; $t_{g}$ : gelationtime; $t_{c}$ : coagulation time. $\left(t_{g}-t_{h}\right)$ : phase II duration; $\left(t_{c}-t_{g}\right)$ : phase III duration; $\left(t_{g}-t_{i}\right)$ : gel solidification phase duration.

Means \pm standard deviation (SD) of three separate determinations. Values sharing same small letter (a-b-c) within a column are not significantly different by Duncan's multiple-range test $(P<0.05)$.

showed that enzymatic hydrolysis is a first-order reaction tightly linked to the amount of casein- $\kappa$.

Moreover, Calvo [20], studying the effect of temperature and fat content on coagulation, noticed that fat content could prevent either the action of the chymosin or the first stages of the destabilized micelles aggregation. Furthermore, this could explain the difference between full fat and low fat milks in hydrolysis step duration where " $t_{h}$ " was lower in the case of full fat milk than for low fat milk.

There was a significant difference $(P<0.05)$ between full fat milks and milk-olive oil emulsion regarding the characteristic point " $t_{i}$ " of the transition step solid/gel. This time " $t_{i}$ " was shorter in the case of the whole milk with a difference of 55.5 minutes compared to milk-olive oil emulsion and of 94.5 minutes in comparison with low fat milk.

The release of casein aggregation at a significant rate was associated with a proteolysis degree situated between $60 \%$ and $80 \%$ depending on renneting conditions [21,22].

The second step, which corresponded to the aggregation of casein micelles beforehand hydrolyzed, proceeded in a particular way in milk-olive oil emulsion. The paracaseins- $\kappa$ association in the case of milk-olive oil emulsion was slower than that of the whole milk. However, the duration of the second step was as important as the milk was rich in fat. This confirmed the results obtained by Larcher [23] which showed the existence of a negative behavior of the milk fat during coagulation and explained this by the big size of the fatty globules blocking the connection between casein micelles.

The comparison between the coagulation aptitude of low fat milks and milk-olive oil emulsion showed that the nature of the fatty globules had a strong influence over the hydrolysis time but a less marked effect over the duration of the coagulation step $\left(t_{g}-t_{h}\right)$. Conversely of what was noticed by Eck and Gillis [24], this study did not show any proportionality between the aggregation speed of destabilized micelles and the progress of the enzymatic reaction.

The last step, corresponding to the reticulation phase, characterized by " $t_{c}-t_{g}$ ", was shorter in the case of the milkolive oil emulsion. This could be explained by higher ash content in curd resulting from the milk-olive oil emulsion (Table 2), probably indicating a significant number of phosphocalcic links established in this case and thus facilitating the phase of gel reorganization.

However, the role of the ionic calcium which influenced the coagulation time $t_{c}$ and the gel firmness could be also explained by the masking of the charged groupings and

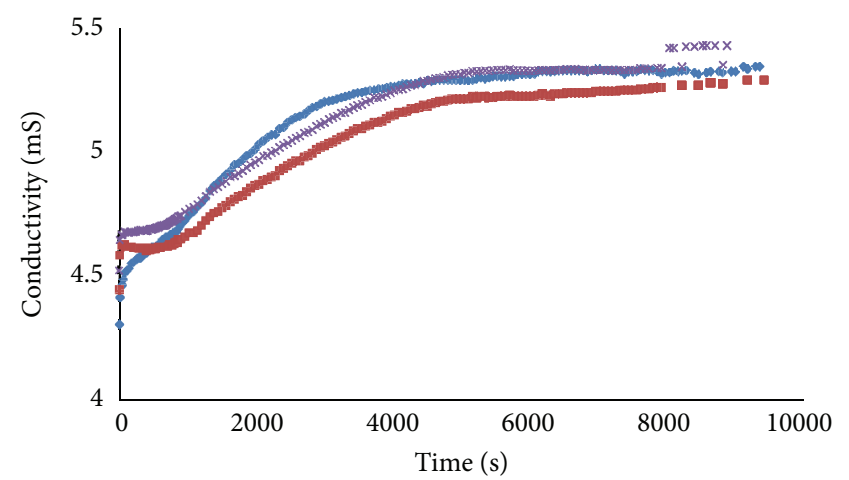

- Full-fat milk

- Low-fat milk

$\times$ Milk-olive oil emulsion

FIGURE 2: Conductivity evolution versus time of various renneted milk samples.

the increase in hydrophobicity [25]. Indeed, it was established that ionic calcium and the availability of micellar calcium played a prevalent role in the reticulation phenomenon [26].

The duration of the reticulation phase was as important as the $\mathrm{Ca} / \mathrm{P}$ ratio increased. According to Remeuf et al. [18] and Eck and Gillis [25], phosphorus could probably intervene in the creation of links between casein micelles. It conferred a real structure to the coagulum whose consistency was firmer as the colloidal calcium phosphate content in milk was higher.

3.2.2. Milk Conductivity. The evolution of the conductivity of milk coagulated by the enzyme showed an exponential pattern (Figure 2).

The curves corresponding to the three milk samples had the same profile. At the beginning of coagulation, an abrupt increase at the first ten seconds was observed then a progressive increase in the conductivimetric signal followed by a prolonged stage were recorded, it is the reorganization phase (Figure 2).

The brutal increase in the conductivity of the various milk samples, just after renneting, was probably due to the release of caseinomacropeptides after the casein- $\kappa$ hydrolysis in the micellar envelope and reflects the high mobility of ions [27].

The establishment of the phosphocalcic bridges and the solubilization of some other colloidal salts during the organization and the reorganization of the gel could explain the progressive increase of the milk conductivity during 
coagulation. The end of coagulation was thus defined by a stabilization of the curd conductivity.

Milk had conductive properties because of the existence of charged compounds such as salts. The distribution of the salt fractions between the colloidal phase and the soluble phase had a significant effect on milk conductivity.

Figure 2 shows that the initial low conductivimetric signal corresponded to the whole milk sample $(4.31 \mathrm{mS})$ followed by low fat milk $(4.45 \mathrm{mS})$. The conductivity of the milk-olive oil emulsion was about $4.53 \mathrm{mS}$. The milk conductivity was tributary not only of its richness in ashes but also of fat content. Indeed, Norberg [27] and Mabrook and Petty [28] reported that fat addition resulted in a reduction in the milk conductance due to the presence of a fine non-conducting membrane which covers the fatty globules.

The evolution of the milk-olive oil emulsion conductivity was similar to that of full fat milk with a light predominance of coagulation during the first period. Then, an inversion of the phenomenon at the 21st minute of coagulation was observed (Figure 2).

At the end of coagulation, measurements of curds conductivity resulting from whole milk reached $5.35 \mathrm{mS}$; that is, an increase of about $18.13 \%$ compared to the initial state. The low fat milk presented a conductivimetric signal of about $5.29 \mathrm{mS}$ with an increase of $19.01 \%$. Concerning the milkolive oil emulsion sample, the curds conductivimetric signal was equal to $5.36 \mathrm{mS}$ with an average improvement of $18.40 \%$ compared to the initial value.

\subsection{Renneted Gels Drainage}

3.3.1. Syneresis Study. It was suggested that syneresis resulted from two different properties of the milky gel: (a) a contraction capacity of the protein framework formed by casein micelles during coagulation expressed by a compaction of the gel and (b) an ability of the gel to evacuate interstitial whey which is a function of permeability and porosity. These characteristics were strictly correlated to the particular conditions under which the gel was formed as well as the physicochemical and chemical composition of the milk.

It was clear from Figure 3 that the serum exudation was more important in the case of the milk-olive oil emulsion $(84.13 \%)$. In the case of the whole milk, the serum exudation was approximately $77.89 \%$ and $81.97 \%$ for low fat milk.

It has been suggested that water could bind directly to fat replacers and fat replacers could interfere with the shrinkage of the casein matrix. Therefore, this lowered the driving force involved in expelling water from curd particles [29].

Relatively large spaces existed in the network where the fat globules were present and acted to interrupt it. When the curd is cut, whey is expelled, and the mesh-like structure shrinks around the fat globules [30]. Milk fat globules in cheeses reduced the degree of shrinking and expelling of whey carrying water-soluble components including proteins and peptides [31]. This might explain that the more the cheese was rich in milk fat, the less they would be expulsed, which was confirmed in this present study (Figure 3).

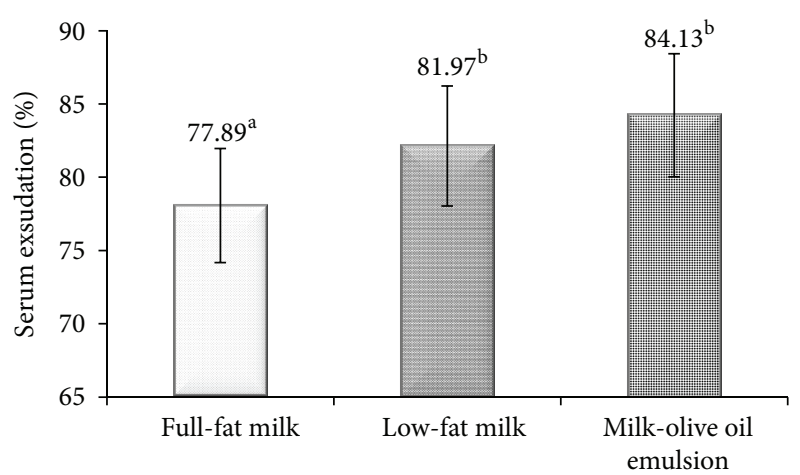

FIGURE 3: Serum exudation rate evolution of various renneted milk samples. Vertical bars indicate standards errors of the means. Identical letters above the bars indicate no significant differences by Duncan's multiple-range test $(P<0.05)$.

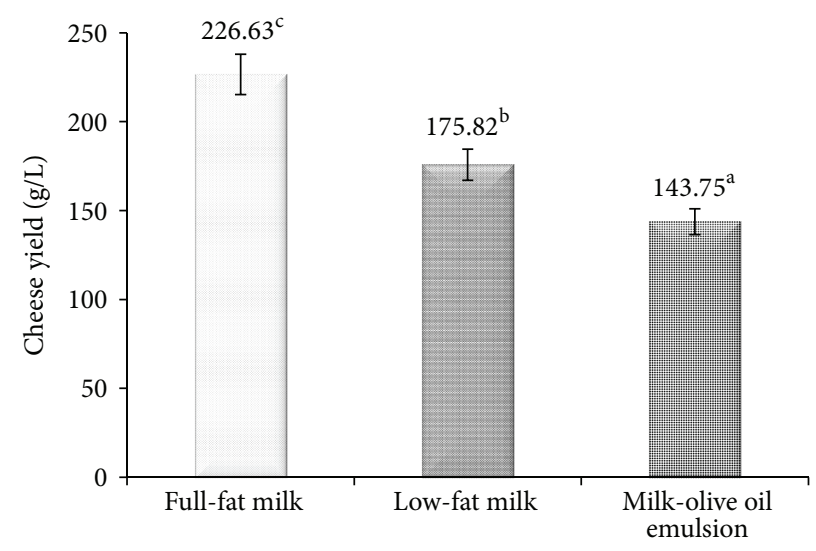

Figure 4: Cheese yields of various renneted milk samples (g/L). Vertical bars indicate standards errors of the means. Identical letters above the bars indicate no significant differences by Duncan's multiple-range test $(P<0.05)$.

Lobato-Calleros et al. [32] noticed that emulsifiers blend contributed to higher emulsified canola oil retention in the reduced fat cheese-like product; therefore, the syneresis phenomenon was inhibited and less whey proteins were expelled from the cheese network. This is not the case in this study where the phenomenon of syneresis was the most intense for the reduced fat cheese-like product. This could be due to the lower water retention capacity of the emulsified olive oil than that of the animal milk fat.

3.3.2. Cheese Yield. Figure 4 represents cheese yields of the various milk samples. It was noticed that low fat milk yielded less cheese than the whole milk which confirmed the result previously found in syneresis section. Thus, it can be concluded that cheeses containing higher milk fat contents exhibited higher yields. This confirmed the results found elsewhere [33,34].

The lower yield of reduced fat cheese-like products, when compared with low-fat cheeses, might be attributed to their higher moisture contents and/or their higher protein contents [29]. 
For the same initial concentration of fat content in milk (Figure 4), the cheese yield was more significant in the case of the curd resulting from low fat milk $(175.82 \mathrm{~g} / \mathrm{L})$ than that of the curd resulting from the milk-olive oil emulsion $(143.75 \mathrm{~g} / \mathrm{L})$. In other words, the quality of milk fat incorporated in milk for the manufacture of reduced fat cheese-like products affected in a significant way its cheese yield. This finding was in agreement with the results of Drake et al. [35] for Cheddar.

Thus, in complex systems, such as the ones under study, a whole range of interactions could take place between the low molecular weight emulsifier molecules, containing lipid and polar fractions and the molecules of the rest of the food components, including proteins, both at the interface as in the network [36].

According to Romeih et al. [12], the yield was also related to the fat content of milk. An overall reduction in yield was inevitable in the production of cheese from low fat milk, since casein and fat contents of the milk, which are the principle components determining cheese yield, were reduced.

\section{Conclusion}

Milk-olive oil emulsion was prepared from the total substitution of milk fat by an emulsified olive oil.

The examination of the turbidimetric signal obtained during enzymatic coagulation showed that the whole milk had a hydrolysis step shorter than that of low-fat milk and milk-olive oil emulsion. The association of paracaseins- $\kappa$ was later than that of the whole milk. The milk conductivity was dependant not only of the milk richness in ashes but also of milk fat content. The drainage aptitude, expressed in terms of expulsed whey weight, was reduced by important dry matter content.

\section{References}

[1] L. Yu and E. G. Hammond, "Modification and analysis of vegetable oil for cheese making," Journal of the American Oil Chemists' Society, vol. 77, no. 9, pp. 911-915, 2000.

[2] C. Lobato-Calleros, C. Ramírez-Santiago, V. J. Osorio-Santiago, E. J. Vernon-Carter, and Y. Hornelas-Uribe, "Microstructure and texture of Manchego cheese-like products made with canola oil, lipophilic and hydrophilic emulsifiers," Journal of Texture Studies, vol. 33, no. 3, pp. 165-182, 2002.

[3] C. Lobato-Calleros, J. Velázquez-Varela, J. Sánchez-García, and E. J. Vernon-Carter, "Dynamic rheology of Mexican Manchego cheese-like products containing canola oil and emulsifier blends," Food Research International, vol. 36, no. 1, pp. 81-90, 2003.

[4] C. Lobato-Calleros, A. Sosa-Pérez, J. Rodríguez-Tafoya, O. Sandoval-Castilla, C. Pérez-Alonso, and E. J. Vernon-Carter, "Structural and textural characteristics of reduced-fat cheeselike products made from W1/O/W2 emulsions and skim milk," LWT-Food Science and Technology, vol. 41, no. 10, pp. 18471856, 2008.

[5] E. Dickinson and J. D. McClements, Advances in Food Colloids, Blackie Academic \& Professional, London, UK, 1996.
[6] I. Felfoul, S. Bornaz, A. Sahli, and H. Attia, "Produits laitiers à base d'une double émulsion d'huile d'olive," Brevet d'invention no. 21577, inscrit sous le No. TN., 2010/0274, 2012.

[7] Norme Française, Détermination du pH du fromage, N.F. V 04281, 1968

[8] S. J. Rowland, "The determination of the nitrogen distribution of milk," Journal of Dairy Research, vol. 9, no. 1, pp. 42-46, 1938.

[9] AFNOR, "Milk and milk products," in Methods of Analysis, AFNOR, Paris, France, 1993.

[10] AOAC, Official Methods of Analysis, Association of Official Analytical Chemists, Washington, DC, USA, 16th edition, 1995.

[11] B. Hocine, F. Remeuf, N. Schneid, and J. Lenoir, "Etude des caractères physicochimiques et des aptitudes fromagères de poudres de laits," Industries Alimentaires et Agricoles, vol. 12, pp. 22-28, 2000.

[12] E. A. Romeih, A. Michaelidou, C. G. Biliaderis, and G. K. Zerfiridis, "Low-fat white-brined cheese made from bovine milk and two commercial fat mimetics: chemical, physical and sensory attributes," International Dairy Journal, vol. 12, no. 6, pp. 525-540, 2002.

[13] G. Kavas, G. Oysun, O. Kinik, and H. Uysal, "Effect of some fat replacers on chemical, physical and sensory attributes of low-fat white pickled cheese," Food Chemistry, vol. 88, no. 3, pp. 381388, 2004.

[14] G. J. O. Martin, R. P. W. Williams, C. Choong, B. Lee, and D. E. Dunstan, "Comparison of rennet gelation using raw and reconstituted skim milk," International Dairy Journal, vol. 18, no. 10-11, pp. 1077-1080, 2008.

[15] J. M. Sadar, “Turbidity science," Technical Information SeriesBooklet No. 11, 1998.

[16] D. J. McClements, "Principles and instrumentation of ultrasonic analysis," Seminars in Food Analysis, vol. 4, pp. 73-93, 1999.

[17] S. Bornaz, J. Sammari, and A. Sahli, "Turbidimetric kinematics of milk during rennet coagulation and relation with composition," in Proceedings of the International Congress on Engineering and Food, Montpellier, France, March 2004.

[18] F. Remeuf, J. Lenoir, and C. Duby, "Etude des relations entre les caractéristiques physicochimiques des laits de chèvre et leur aptitude à la coagulation par la présure," Lait, vol. 69, no. 6, pp. 499-518, 1989.

[19] S. B. Lomholt and K. B. Qvist, "Relationship between rheological properties and degree of $\kappa$-casein proteolysis during renneting of milk," Journal of Dairy Research, vol. 64, no. 4, pp. 541-549, 1997.

[20] M. M. Calvo, "Influence of fat, heat treatments and species on milk rennet clotting properties and glycomacropeptide formation," European Food Research and Technology, vol. 214, no. 3, pp. 182-185, 2002.

[21] J. A. Lucey, "Formation and physical properties of milk protein gels," Journal of Dairy Science, vol. 85, no. 2, pp. 281-294, 2002.

[22] M. Mellema, P. Walstra, J. H. J. van Opheusden, and T. van Vliet, "Effects of structural rearrangements on the rheology of rennetinduced casein particle gels," Advances in Colloid and Interface Science, vol. 98, no. 1, pp. 25-50, 2002.

[23] I. Larcher, La fabrication fromagère fermière, Centre Fromager de Carmejane, Le Chaffaut-Saint-Jurson, France, 2002.

[24] A. Eck and J. C. Gillis, Cheese Making from Science to Quality Assurance, Tec \& Doc, Lavoisier, Paris, France, 3rd edition, 2000.

[25] A. H. Eck and J. C. Gillis, Le fromage, Tec \& Doc, Lavoisier, Paris, France, 3rd edition, 1997. 
[26] C. Alais and G. Linden, "Lait et Produits laitiers. 4-Les matières azotées-Les caséines," in Abrègé Biochimie Alimentaire, C. Alais and G. Linden, Eds., vol. 3, pp. 162-185, M sur Masson, Paris, France, 1994.

[27] E. Norberg, "Electrical conductivity of milk as a phenotypic and genetic indicator of bovine mastitis: a review," Livestock Production Science, vol. 96, no. 2-3, pp. 129-139, 2005.

[28] M. F. Mabrook and M. C. Petty, "A novel technique for the detection of added water to full fat milk using single frequency admittance measurements," Sensors and Actuators B, vol. 96, no. 1-2, pp. 215-218, 2003.

[29] D. J. McMahon, M. C. Alleyne, R. L. Fife, and C. J. Oberg, "Use of fat replacers in low fat Mozzarella cheese," Journal of Dairy Science, vol. 79, no. 11, pp. 1911-1921, 1996.

[30] D. J. McMahon, C. J. Oberg, and W. McManus, "Functionality of Mozzarella cheese," Australian Journal of Dairy Technology, vol. 48, pp. 99-104, 1993.

[31] S. Gunasekaran and M. M. Ak, Cheese Rheology and Texture, CRC Press, Boca Raton, Fla, USA, 2003.

[32] C. Lobato-Calleros, J. Reyes-Hernández, C. I. Beristain, Y. Hornelas-Uribe, J. E. Sánchez-García, and E. J. Vernon-Carter, "Microstructure and texture of white fresh cheese made with canola oil and whey protein concentrate in partial or total replacement of milk fat," Food Research International, vol. 40, no. 4, pp. 529-537, 2007.

[33] Y. Lou and K. F. Ng-Kwai-Hang, "Effects of protein and fat levels in milk on cheese and whey compositions," Food Research International, vol. 25, no. 6, pp. 445-451, 1992.

[34] M. A. Rudan, D. M. Barbano, J. J. Yun, and P. S. Kindstedt, "Effect of fat reduction on chemical composition, proteolysis, functionality, and yield of Mozzarella cheese," Journal of Dairy Science, vol. 82, no. 4, pp. 661-672, 1999.

[35] M. A. Drake, W. Herrett, T. D. Boylston, and B. G. Swanson, "Lecithin improves texture of reduced fat cheeses," Journal of Food Science, vol. 61, no. 3, pp. 639-642, 1996.

[36] J. Holstborg, B. V. Pedersen, N. Krog, and S. K. Olesen, "Physical properties of diglycerol esters in relation to rheology and stability of protein-stabilised emulsions," Colloids and Surfaces B, vol. 12, no. 3-6, pp. 383-390, 1999. 

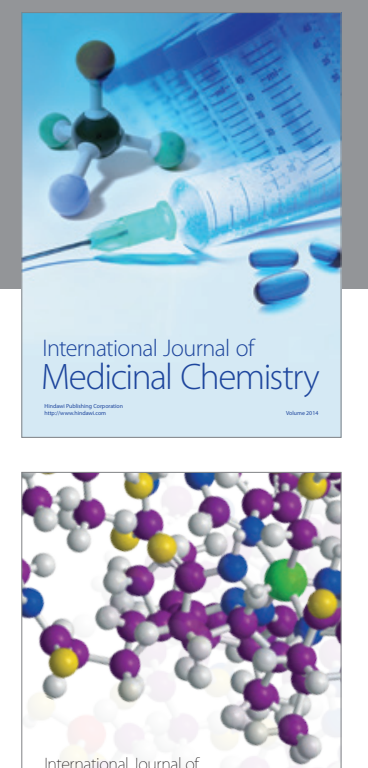

\section{Carbohydrate} Chemistry

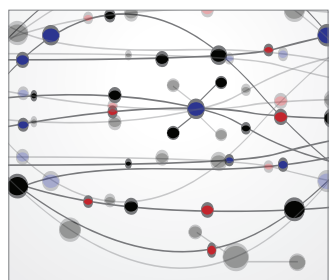

The Scientific World Journal
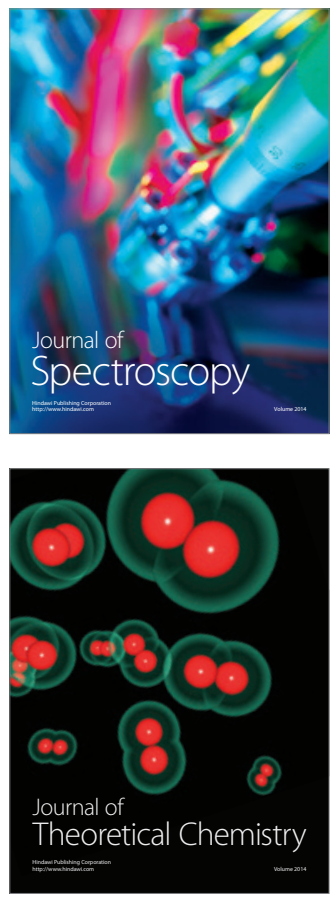
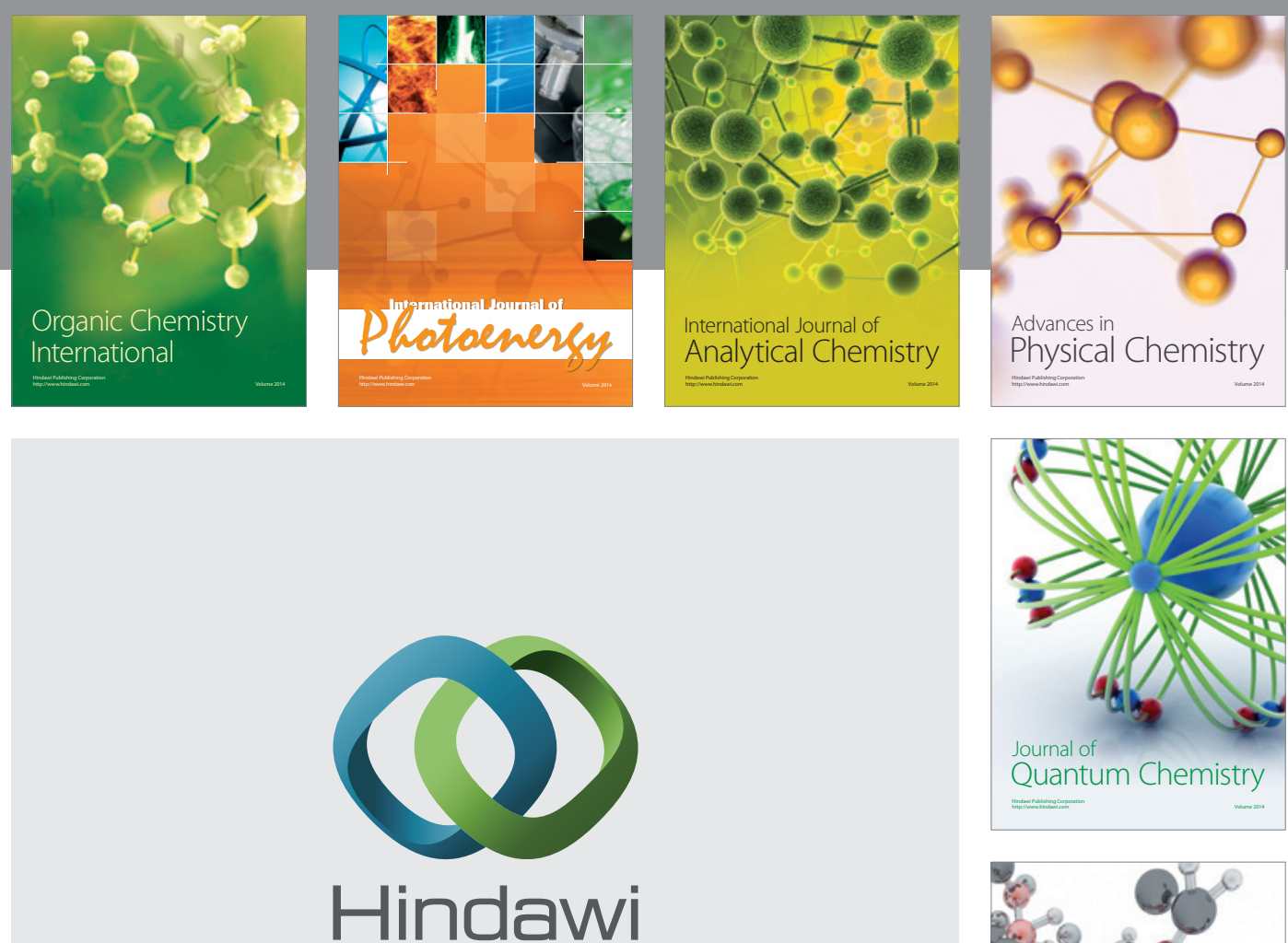

Submit your manuscripts at

http://www.hindawi.com

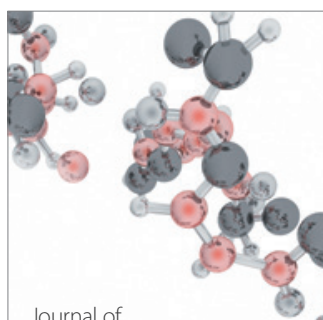

Analytical Methods

in Chemistry

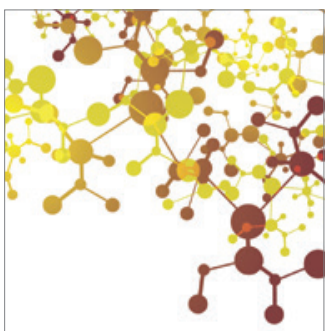

Journal of

Applied Chemistry

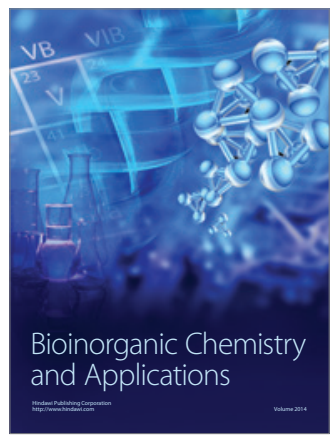

Inorganic Chemistry
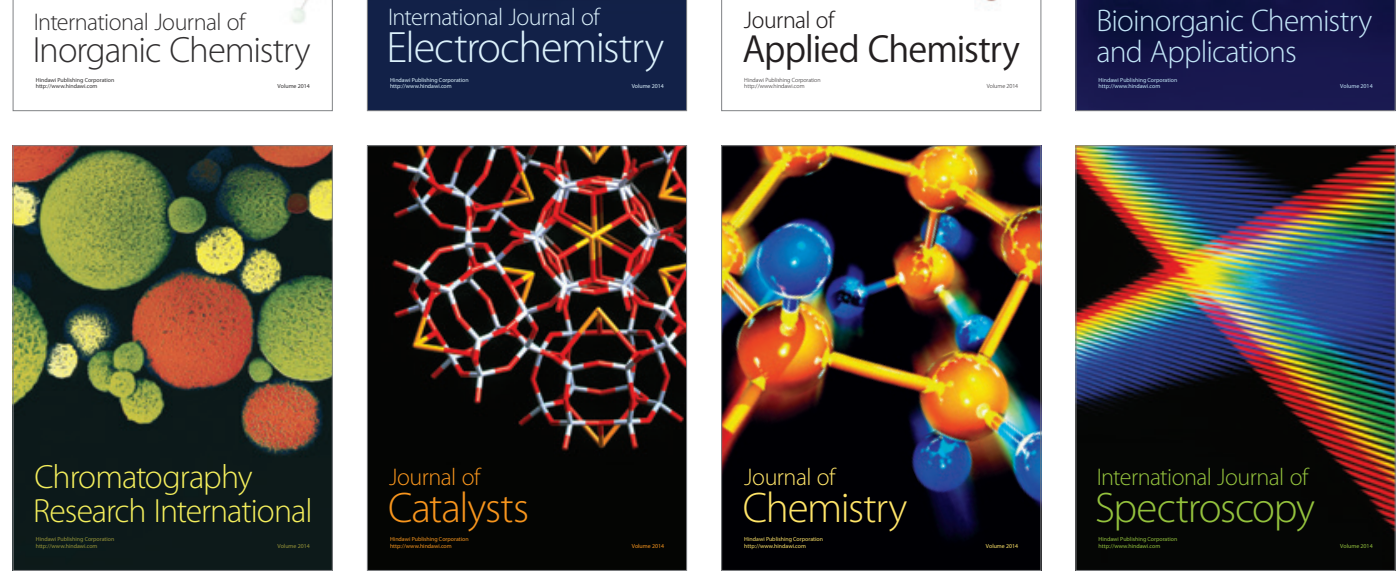